Науковий вісник Чернівецького університету імені Юрія Федьковича: Історія. - № 1. - 2020.- С. 78-86 History Journal of Yuriy Fedkovych Chernivtsi National University. - № 1. -2020 . - pp. 78-86 DOI https: /doi.org/10.31861/hj2020.51.78-86

hj.chnu.edu.ua

УДК 94:327(5-191.2)«1992/2020»

(С) Олександр Аулін* (Київ)

\title{
СПЕЦИФІКА СТРАТЕГІЧНИХ КОМУНІКАЦІЙ ТУРЕЧЧИНИ НА ПОСТОТТОМАНСЬКОМУ ПРОСТОРІ (1992-2020 рр.)
}

У статті досліджується своєрідність стратегічних комунікаиій, щзо здійснюються Турецькою Республікою на постоттоманському просторі. Аналізуються можсливі наслідки від втілення Анкарою в життя політичної ідеології, щзо відчуває значного впливу кониепиії «неоосманізму», орієнтованої на відновлення турещького домінування на теренах колишньої Оттоманської імперії. Звертається увага на причини вибору вищим керівництвом Турецької Республіки об'єктів для участі в інтеграчійних проєктах із виходом за межі власне постоттоманського ареалу. У результаті проведення дослідження запропоновано розподіл інтеграційних пріоритетів Турецької Республіки на 3 періоди, які корелюють з основними етапами розвитку загальнотуречьких, загальноісламських $i$ загальносвітових історичних процесів. Показано, щь теперішній зовнішньополітичний вектор Турецької Республіки, великою мірою сформований під впливом доктрини неоосманізму, на тлі намагань Анкари щзодо виходу на позиції надрегіонального лідерства викликатиме конфліктні ситуації з країнами, що вже мають подібний статус і не бажають приймати нового гравия до свого кола. Це потребує серйозних змін концептуального характеру у відносинах Турецької Республіки зі своїми стратегічними партнерами, насамперед - західними, а також інтенсифікаиії стратегічних комунікацій на иьвому напрямі. Згадані особливості стратегічних комунікачій Туреччини мають суттєвий вплив на розвиток українсько-турецьких відносин у цілому.

Ключові слова: стратегічна комунікація, пріоритети, історичний процес, hard power, soft рожег, неоосманізм, османізм, тюркізм, стратегічна глибина.

\section{Aleksand Aulin (Kyiv) \\ SPECIFICS OF TURKEY'S STRATEGIC COMMUNICATIONS IN THE POSTOTTOMAN SPACE (1992-2020)}

Abstract. The article analyzes the nature of the impact of strategic communications of Turkey in the territories that were previously part of or under the political and religious influence of the Ottoman Empire, and explores the possible consequences of such interference for Ukraine. It is shown that the current foreign policy vector of the Republic of Turkey, largely formed under the influence of the doctrine of neo-Ottomanism, against the background of Ankara's efforts to reach the position of supraregional leadership. As a result of the study, the division of integration priorities of the Republic of Turkey into 3 periods is proposed, which correlate with the main stages of development of all-Turkish, all-Islamic and world historical processes. The first - from 1920 to the middle / end 1930s, the second from the

* к. філос. н., с.н.с. Державна установа «Інститут всесвітньої історії НАН України».

$\mathrm{PhD}$ in Philosophy, Senior Research Fellow, State Institution «Institute of World History of the National Academy of Sciences of Ukraine». orcid.org/0000-0001-7304-7182

E-mail:sozionik@gmail.com 
mid-1930s to the late 1980s / early 1990s, and the third from the early 1990s to the present. The first stage can be described as a period of «internal communication». 1920 became another bifurcation point in the history of the Turkish ethnic group. By this time, the Ottoman Empire and its allies had been defeated in the First World War. With the help of the latter, the Kemalists managed to stop the process of fragmentation of the interior of Turkey from the beginning, and eventually move to the return of the temporarily rejected territories. For the second period of communication efforts of the Republic of Turkey, the priority was to join the world's leading security and political associations. In the context of our study, this stage can be described as a "period of forced external communication", when Ankara was to play the role of a "junior» partner of the United States and Great Britain. The period from the early 1990s to the present in the political history of the TR can be defined as a «stage of active external communication». Unlike the previous one, during this period, Turkey is increasingly acting as a subject of world politics, fighting for the status of regional leader.

According to the results of the analysis, the Black Sea region will remain one of the most important areas of strategic communications for the Republic of Turkey in the long run. The most serious obstacle to Turkey's sole leadership on the Black Sea is Moscow's geopolitical ambitions and the United States' intention to extend its role as an arbitrator. The presence of the Muslim population on the territory of Ukraine, first of all, Crimean Tatars in the Autonomous Republic of Crimea occupied by the Russian Federation, is a constant factor that contributes to the further development of Ukrainian-Turkish strategic communications.

Keywords: strategic communication, priorities, historical process, hard power, soft power, neoOttomanism, Ottomanism, Turkism, strategic depth.

Постановка наукової проблеми та її значення. Сучасна Турецька Республіка (ТР) здійснює стратегічні комунікації відповідно до політичних пріоритетів, якими передбачається інтеграція на основі турецького регіонального лідерства на територіях, що раніше входили до Оттоманської імперії або були населені етнічними тюрками й відчували помітного релігійного i/або політичного впливу з боку Туреччини. Така позиція зумовлює жорстку протидію з боку конкурентів (країни Заходу на чолі зі США, РФ, частково КНР тощо). Головна причина в тому, що політичне, а найчастіше, змішане військово-політичне та релігійне лідерство надає великі переваги економічного та стратегічного характеру. Подібний розвиток подій напряму зачіпає державні інтереси України, де мешкає досить велика, етнічно близька туркам мусульманська діаспора. Обидві держави розвивають двостороннє стратегічне співробітництво, й Анкара постійно заявляє про підтримку суверенітету і територіальної цілісності України. Поруч з цим інтеграційні зусилля ТР, які значною мірою відчувають вплив концепції неоосманізму, насамперед спрямовані на зміцнення й розвиток зв'язків 3 тюркськими народами. Одним із таких проявів $є$ створення тюркських військово-політичних союзів за етнічною ознакою, а також спроби відновлення впливу на розширеному постосманському просторі. Таким чином, розгляд пріоритетів сучасних турецьких стратегічних комунікацій набуває великого значення з огляду на стан партнерських відносин Києва, з одного боку, зі США та їх західними союзниками, а з іншого - з Анкарою.

Аналіз останніх досліджень із цієї проблеми. У ході дослідження проаналізовані роботи вітчизняних і закордонних вчених, що опікуються близькосхідною i/aбо безпосередньо турецькою проблематикою, таких як: В. Аватков та А. Бадранов ${ }^{1}$, Д. Бачард ${ }^{2}$, Г. Шабан ${ }^{3}$, М. Ганіоглу ${ }^{4}$ Ю. Мавріна $^{5}$, О. Мейгун ${ }^{6}$, С. Рибалко

У працях цих авторів розглянуто багато аспектів сучасної зовнішньої політики Анкари, в тому числі тих, що належать до сфери стратегічних комунікацій (тобто системного, скоординованого використання комунікативних можливостей держави, спрямованих на просування їі цілей шляхом виявлення й застосування ефективних методів активації та підтримки певних типів поведінки з боку цільових аудиторій). При цьому однак, під час згаданих розвідок, не враховувався такий важливий чинник впливу на стратегічні комунікації Анкари, як ідеологія неоосманізму, що робить наше дослідження актуальним у теперішніх умовах. 
Формулювання мети статті. Мета роботи - розглянути специфіку стратегічних комунікацій сучасної Туреччини, що сформовані під впливом концепції неоосманізму, як складову світового історичного процесу.

Виклад основного матеріалу. За останнє століття сегмент міжнародних комунікацій Турецької Республіки, що підпадає під вищенаведене визначення стратегічних комунікацій, помітно змінювалися під впливом зовнішньо- та внутріполітичних обставин. При цьому зовнішньополітичний тиск на Анкару з боку країн Заходу, насамперед США та Великої Британії, поступово перетворювався 3 основного на другорядний чинник. На наш погляд, згадані історичні події досить продуктивно розглядати в рамках трьох основних етапів. Перший - 1920 року до середини/кінця 1930-х років, другий - з середини 1930-х до кінця 1980-х/початку 1990-х років і третій - з початку 1990-х років до теперішнього часу.

Перший етап можна позначити як період «внутрішньої комунікації». 1920 рік став черговою точкою біфуркації в історії турецького етносу. До цього часу відбулася поразка Оттоманської імперії та її союзників у Першій світовій війні. Стамбул втратив контроль над більшістю володінь в Європі, Африці й на Близькому Сході. Столиця з протоками Босфор і Дарданелли (далі - протоки) була окупована військами Антанти. Османська армія роззброєна й розформована. Парламент розігнаний. 3 півдня країни в бік Анкари рухалися сили грецького окупаційного корпусу. Тривали курдські повстання. Реалізація домовленостей, передбачених Севрським мирним договором, могла призвести до відторгнення значних частин території, що належать сучасній ТР. Південно-східні райони передбачалося включити до складу Демократичної республіки Вірменія, яку планувалося створити. Галліполі, Едірне та Ізмір передати Греції. Теперішня провінція Хатай входила до складу підмандатної Сирії.

Саме в таких умовах майбутній Ататюрк зробив пріоритетами своєї діяльності об'єднання політичних і військових зусиль турецького народу на національному підгрунті, використовуючи при цьому наявні на той момент можливості у сфері стратегічних комунікацій. За допомогою останніх кемалістам вдалося спочатку зупинити процес фрагментації внутрішніх областей Туреччини, а 3 часом перейти до повернення тимчасово відторгнутих територій. Мустафа Кемаль скликав в Анкарі національний парламент - Велике Національне Зібрання Туреччини (ВНЗТ). Очоливши ВНЗТ і новий уряд, турецький лідер розірвав усі попередні договори Османської імперії. Щоб прорвати військово-дипломатичну блокаду Антанти, він пішов на підписання угод із Радянською Росією. Грецький експедиційний корпус був розгромлений. Курдська проблема тимчасово заморожена. У результаті прибічники Ататюрка завадили створенню вірменських та грецьких незалежних анклавів в Анатолії. Кемалісти ліквідували інститути Османської імперії, Султанату і Халіфату. На основі принципів націоналізму, лаїцизму і демократії створили Турецьку Республіку. У рамках вестернізації здійснили індустріалізацію, реформу збройних сил, освіти тощо. Поруч із цим Ататюрку вдалося налагодити відносини з провідним країнами Заходу й уникнути зайвого політичного впливу 3 боку колишнього СРСР 9 .

У контексті внутрішньої комунікації прихильниками Ататюрка досить широко використовувалася концепція «тюркізму» (тюркського націоналізму), який став підгрунтям для об’єднавчих процесів в етнічному середовищі країни. Тюркізм, також як османізм був спрямований на створення єдиної нації. Оттоманська нація повинна була складатися з різних рівноправних народів. Тюркістська доктрина бачила кінцевою метою створення максимально однорідної, моноетнічної нації. Тому основу тюркізму його ідеологи бачили в єдності національної свідомості, мови, культури та історії. Подібна державна політика призвела до втрати в Туреччині вірменами, євреями й греками статусу автономних і наближених до них іноетнічних громад, котрий надавався за умовами міжнародних договорів, що укладалися до 1920 року. Курди отримали назву «гірських турків» і примушувалися до використання турецької мови, одягу, освіти тощо.

У роки, що ми описуємо, подібні, наближені до hard power, заходи на основі ідеології тюркізму дозволили уберегти Туреччину від повного розпаду. При цьому, однак, вони заклали «міну уповільненої дії» під саму модерну державність Турецької Республіки, трансформувавшись на почат- 
ковому етапі політичної історії ТР в один із наріжних каменів кемалізму. У загальноісторичному контексті цей період турецької історії збігся в часі із заключним етапом формування світової колоніальної системи. Водночас у мусульманському світі завершався процес підготовки до створення ісламістських інститутів. Кемалістська Туреччина стала однією з небагатьох країн ісламського світу, якій вдалося зберегти власну незалежність. Прагматична концентрація основних зусиль на першочерговому вирішенні внутрішніх проблем поступово створила базу для початку реалізації зовнішніх об'єднувальних проєктів.

Для другого періоду комунікаційних зусиль Турецької Республіки пріоритетним був вступ до провідних світових безпекових і політичних об'єднань. У контексті нашого дослідження цей етап може бути позначений як «період вимушеної зовнішньої комунікації», коли Анкара мала грати роль «молодшого» партнера США й Великобританії. В загальноісторичному плані цей період співпадав із формуванням антагоністичного світоустрою, поділеного на соціалістичну і капіталістичну системи, що змагалися в умовах холодної війни. В локальному сульманському - 3 першим етапом ісламського відродження.

Особливо важливими для Туреччини були роки Другої світової війни, коли політичне керівництво республіки врахувало досвід участі Османської імперії у Великій війні, зробило правильні висновки й твердо вело країну шляхом нейтралітету. Завдяки гнучкій зовнішній політиці ТР напередодні війни за допомогою Франції та Великобританії, яких бентежило посилення головного континентального суперника - Німеччини та їі союзників, Анкарі вдалося вирішити важливі проблеми. Йдеться про вступ до Ліги Націй, відновлення турецького контролю за протоками й повернення під турецьку юрисдикцію провінції Хатай. Цьому сприяло приєднання ТР до нового політичного проєкту, що створювався під егідою Парижа, - Балканської Антанти, а також підписання безпекових угод із Лондоном. Прагматичний вибір на благо турецького суспільства і тверде відстоювання його інтересів перед представниками обох блоків, що змагалися один з одним, дозволили Анкарі мінімізувати негативні наслідки від чергового загальносвітового кровопролиття й по завершенні бойових дій посилити свої політичні позиції на міжнародній арені.

Дотримання політики нейтралітету майже до самого завершення війни і вдалий перехід на бік західного крила антигітлерівської коаліції дозволив ТР у листопаді 1945 р. вступити до ООН, а також зберегти власну територіальну цілісність. У другій половині 1940-х рр. СРСР намагався «назавжди вирішити проблему проток» і переглянути російсько-турецькі договори 1921 року щодо приналежності низки північно-західних провінцій Туреччини. Подібний тиск з боку Москви, яка формувала політико-економічну й військову структуру соціалістичного табору, підштовхнув Анкару до вступу в НАТО. Крім того, Туреччина в ті роки стала членом Ради Європи (РС), Організації економічного співробітництва та розвитку (ОЕСР), Організації ісламського співробітництва (ОІК), Організації безпеки і співробітництва в Європі (ОБСЄ) та навіть асоційованим членом Європейського Союзу (СС).

Знаковою подією стала ситуація з членством Туреччини в ОІК. До середини 1970-х років Анкара брала участь у діяльності організації на рівні міністра іноземних справ. Така двоїста позиція була викликана тим, що, з одного боку, ТР ще була переважно світською, кемалістською за сутністю державою. 3 іншого - це відгороджувало республіку від країн Близького Сходу, які вже отримали доступ до значних енергетичних та фінансових ресурсів. Крім того, Кіпрська криза середини 1970-х років викликала напруженість у відносинах Анкари з Вашингтоном і його західними союзниками. У свою чергу країни ОІК підтримали Туреччину. Всередині самої ТР у ці роки вперше з моменту заснування республіки таємні прихильники тарикату Накшбанді створили новий загальнонаціональний ісламістський рух «Національний погляд»/Milli Görüş (НП). У структурному та ідеологічному відношеннях НП був близький єгипетським «Братам-мусульманам». Надалі рух став базовою організацією для більшості ісламістських партій Туреччини ${ }^{10}$.

Період з початку 1990-х років до теперішнього часу в політичній історії ТР можна дефініціювати як «етап активної зовнішньої комунікації». На відміну від попереднього, в цей період Туреччина все частіше виступає як суб'єкт світової політики, що веде боротьбу за статус регіонального 
лідера. В останні роки основним пріоритетом для Анкари, зокрема в інтеграційній сфері, стає вихід на надрегіональний рівень. Це потребує серйозних змін концептуального характеру у відносинах Анкари зі своїми стратегічними партнерами, насамперед - західними, а також інтенсифікації стратегічних комунікацій на цьому напрямі. Зокрема, для офіційної Анкари характерним стає досить інтенсивне використання технологій soft power. Згадана стадія у загальноісторичному контексті співпадає з розквітом глобалізаційних процесів на тлі формування постмодерного, постіндустріального суспільства, основою якого є інформаційна складова. 3 приходом на початку 2000-х до влади в Туреччині поміркованих ісламістів - Партії справедливості та розвитку (ПСР) на чолі з Реджепом Ердоганом, відбувається інсталяція багатьох елементів концепції неоосманізму до турецької політичної системи.

Одним із перших термін «неоосманізм» використав політичний аналітик, тюрколог і журналіст Девід Барчард. Аналізуючи політичну ситуацію в ТР за часів прем'єрства Тургута Озала, він писав: «У політичних промовах, газетах, як і шкільних підручниках, особлива увага приділяється турецькій державі й необхідності зміцнювати її єдність і владу. ... Історія Османської імперії - від iii розквіту в XVI в. до занепаду у XIX ст. - зазвичай подається у безпосередньому зв'язку з сьогоденням. Почуття приналежності до спадкоємців великої імперії забарвлює й турецькі офіційні підходи, i, певною мірою, громадську думку» ${ }^{11}$. Оцінки ролі «неоосманізму» в політичній спадщині цього державного діяча істотно різняться. Так, Шабан Чалиш вважає, що саме «неоосманізм» був для Озала ключовою частиною політичного і соціального бачення ідентичності Туреччини та їі орієнтації $^{12}$. На думку ще одного відомого турецького дослідника Омера Таспінара, «неоосманізм» $€$ швидше спробою «збалансувати й розширити горизонти кемалізму та його надмірну одержимість західною ідентичністю...» ${ }^{13}$.

В концептуальному плані неоосманізм був оформлений Ахметом Давутоглу (на той час професором університету, в подальшому одним із вищих керівників ТР) і знайшов віддзеркалення в книзі «Стратегічна глибина. Міжнародне становище Туреччини». Її сутність складається 35 основних принципів. Перший - це баланс між свободою і безпекою. Легітимність будь-якого політичного режиму виходить з його здатності забезпечити безпеку і свободу ії громадян; ця безпека не повинна досягатися ціною свобод і прав людини в державі. Другий - базується на проведенні політики «нульових проблем з сусідами». Відносини Туреччини з їі сусідами сьогодні все більше йдуть шляхом співпраці. Між ТР і сусідніми країнами розвивається економічна взаємозалежність. Третій принцип дії - це попереджуюча мирна дипломатія, метою якої є вжиття заходів до виникнення кризової ситуації та досягнення критичного рівня. Четвертий принцип - це прихильність багатовекторній зовнішній політиці. Взаємодія Туреччини з іншими світовими акторами суто прагматична й скерована на те, щоб кожний вектор власної політики лише доповнював інші, а не конкурував $з$ ними. Така політика простежується в турецьких стратегічних відносинах зі США через двосторонні стратегічні зв'язки двох країн і НАТО. Поруч з цим такий курс включає в себе процес інтеграції в ЄС, проведення скоординованої політики в Євразії, добросусідство з Росією та іншими країнами регіону як невід'ємні частини послідовної зовнішньої політики Туреччини, що служать доповненням один до одного. Це означає, що добрі відносини з сусідніми країнами не є альтернативою відносинам з СС, а союзницькі відносини зі США не суперечать партнерству з Росією або з Китаєм. П'ятий принцип грунтується на ритмічній дипломатії, яка прагне забезпечити Туреччині активнішу роль у міжнародних відносинах. Туреччина тут виступає як активний учасник процесу створення глобального порядку в культурному, економічному, політичному сенсі. Дотримання вищезгаданих принципів відбувається на стратегічних комунікаціях Анкари в напрямку підвищеної зовнішньополітичної активності на розширеному постоттоманському просторі. Про це, зокрема, свідчить статус ТР у міжнародних організаціях, який вона створювала або до яких вона входила, починаючи з 1990-х років ${ }^{14}$.

Хоча республіки колишнього СРСР і області РФ із переважно тюркським населенням не входили безпосередньо до складу Оттоманської імперії, проте їм приділена значна увага в концепції «стратегічної глибини» М. Давутоглу. Цілком природно, що перші зовнішні комунікаційні зусилля 
Анкари на початку 1990-х років були зосереджені саме на цьому напрямі. Одним із таких кроків стало створення в 1993 році міждержавної комунікаційної платформи у форматі Міжнародної організації тюркської культури (TÜRKSOY). У декларації TÜRKSOY йдеться про те, що повалення соціалістичних ідеалів призвело до посилення тенденції консолідації культур на їхньому етнорівні. У цьому контексті особливого значення і пріоритетності набувають заходи з виявлення соціоідентичності тюркомовних народів, збереження, вивчення і примноження їхнього культурного різноманіття. Таким чином, «Створення TÜRKSOY спрямовано, в першу чергу, на відродження традицій духовного спілкування (комунікації) між спорідненими народами і країнами тюркомовного ареалу» ${ }^{15}$. Перемови про створення TÜRKSOY почалися після розпаду CРCP у 1992 р. Головний офіс організації розташовується в Туреччині, яка $є$ також головним фінансовим донором організації. Про політичний вплив TÜRKSOY свідчить конфлікт, що відбувся під час загострення російсько-турецьких відносин унаслідок збитого турецькими ВПС ув 2015 році в Сирії російського бомбардувальника. Як заходи у відповідь Москва вимагала від тюркських суб'єктів федерації (Саха-Якутія, Башкортостан, Татарстан тощо) розірвати двосторонні зв'язки з TÜRKSOY. Однак у цілому культурний статус TÜRKSOY створював проблеми для більш активних стратегічних комунікацій між тюркомовними країнами, кінцевою метою якого було створення політико-економічного, а згодом, можливо, військового союзу під егідою Анкари. Задля цього в 2009 р. була утворена Тюркська рада, до якої, крім ТР, увійшли Туркменістан, Казахстан, Киргизстан і Азербайджан. Активні стратегічні комунікації Анкари сприяли зміцненню не тільки культурно-економічних відносин, але й формуванню військових коаліцій. Так, у рамках організації «Рада тюркомовних країн» діє «Тюркська військова рада». У 2013 р. Азербайджан, Туреччина, Киргизія і Монголія заснували «Збройні сили тюркомовних країн» тощо ${ }^{16}$.

У 1992 р. Туреччиною було ініційовано створення Чорноморського економічного співробітництва (ЧЕС) з підписанням Стамбульської декларації, яка визначала основні напрями діяльності цього міждержавного об'єднання. Прагнучи зайняти позицію лідера в новому інституті, турки взяли на себе фінансування Міжнародного секретаріату та Парламентської асамблеї ЧЕС. В Анкарі був створений спеціалізований Статистичний центр. Представник Туреччини $є$ президентом Чорноморського банку торгівлі та розвитку. ТР підтримує проєкти реалізації єдиних транспортних і енергетичних систем навколо Чорного моря, їй належить ідея формування в регіоні зони вільної торгівлі. Анкара запропонувала створити Центр торгівлі та інвестицій ЧЕС. Турецьке керівництво вважає організацію ЧЕС «невід'ємним фактором миру, стабільності і процвітання в регіоні» ${ }^{17}$. Анкара сподівається, що розвиток організацію ЧЕС в окресленому напрямі дозволить, зокрема, частково компенсувати втрати, що виникнуть у разі остаточної відмови від надання Туреччині статусу повноправного члена Євросоюзу.

Серед теперішніх пріоритетів стратегічних комунікацій Анкари - інформаційне забезпечення участі ТР у вирішенні військово-політичних конфліктів в Африці та на Близькому Сході. У 2020 р. Туреччина надала військову підтримку міжнародно визнаному уряду Лівії. У результаті Анкара опинилася у числі країн, які протистоять лівійському військовому лідеру Х. Хафтару. На сьогодні це РФ, ОАЕ, Саудівська Аравія та Єгипет. Крім того, збройні сили Туреччини на території Сирії провели 2 великомасштабні військові операції проти залишків Ісламської Держави та курдських повстанців. Під час проведення операцій «Щит Євфрату» й «Оливкова гілка» турецьким силовикам і підконтрольним їм підрозділам сирійської опозиції вдалося ліквідувати загрозу створення біля південного кордону ТР єдиного курдського анклаву. Також був встановлений контроль над прилеглими районами Сирії, де мешкає значна кількість близьких до турків етносів. У рамках введення турецьких військ для боротьби проти загонів Курдської робітничої партії у Північному Іраку, також як у Сирії, Анкара спиралася на стратегічні комунікації з місцевими етнічними тюркськими групами.

Одним із ключових моментів для розуміння пріоритетів сучасних стратегічних комунікацій Туреччини стала ситуація навколо Катарської кризи. Незважаючи на позицію США і Саудівської Аравії, які номінально вважаються стратегічними партнерами ТР, і чиї дії стали однією з основних 
причин виникнення в 2017 р. кризової ситуації, Анкара не скасувала своє рішення направити до Катару 3000 власних військовослужбовців. Ряд турецьких експертів і політиків трактував таку позицію як повернення до традицій столітньої давнини, коли значна частина Катару перебувала під юрисдикцією і заступництвом Туреччини.

3 моменту здобуття Україною незалежності, Анкара незмінно заявляє про повагу до національного суверенітету нашої країни і наміри розвивати подальші двосторонні відносини в рамках стратегічного партнерства. Це стосується і сфери економіки. Однак, за даними Держслужби статистики України, у 2016 р. вітчизняні виробники експортували до Туреччини товарів загальною вартістю \$ 2,49 млрд. Це на рівні аналогічних показників експорту в Єгипет (\$2,26 млрд), Польщу (2,2 млрд) і нижче, ніж в РФ (\$ 3,59 млрд). У той же час, після падіння на $29 \%$ обсягів російського експорту до ТР, у 2016 р. він становив \$ 13,69 млрд ${ }^{18}$. На піку російсько-турецького конфлікту через збитий бомбардувальник, генеральним підрядником будівництва нового терміналу та двох міжтермінальних тунелів в аеропорту Шереметьєво була обрана турецька компанія «Renaissance Construction» ${ }^{19}$. У 2017 році під час зустрічі російського й турецького президентів було підтверджено, що фінансування РФ будівництва першої у Туреччині атомної електростанції «Аккую» буде здійснюватися відповідно до проєкту, вартість якого становить близько $\$ 20$ млрд ${ }^{20}$.

За словами генерального консула Туреччини в Одесі, Анкару в гуманітарній сфері відносин 3 Україною в першу чергу цікавлять питання, пов'язані з кримськими татарами, турками-месхетинцями та гагаузами. Таким чином, в зону «особливих» інтересів ТР потрапляють Крим, частина Одеської області i, меншою мірою, Донбас. Серед українських мусульман, в етноісторичному контексті, найбільш близькими туркам є кримські татари. Двосторонні стратегічні комунікації демонструють стійку динаміку розвитку. Цьому сприяє і наявність у ТР численної кримськотатарської діаспори (близько 4 мільйонів осіб), активна частина якої об’єднана в національно-культурні товариства дернекі. Незважаючи на активне політико-економічне співробітництво з РФ, після російської окупації Криму Анкара періодично здійснює політичні демарші із засудженням репресивної політики Кремля щодо місцевих мусульман.

Отже, з викладеного вище можна зробити такі висновки:

- сучасні пріоритети стратегічних комунікацій Туреччини стосуються Причорномор'я, Центральної Азії, Близького Сходу і Північної Африки;

- на специфіку сучасних стратегічних комунікацій ТР значний вплив здійснює концепція неоосманізму, про що, зокрема, свідчить збіг зон життєво важливих інтересів, зазначених у концептуальній роботі А. Давутоглу, з головними зонами сучасної економічної та релігійно-політичної активності Анкари;

- теперішній зовнішньополітичний вектор ТР (відродження впливу на постосманських територіях, а також у центральноазіатських республіках колишнього СРСР) на тлі намагань Анкари щодо виходу на позиції надрегіонального лідерства викликатиме конфліктні ситуації з країнами, що вже мають подібний статус (США з союзниками, Китай, РФ) і не бажають приймати нового гравця до свого кола. Це потребує серйозних змін концептуального характеру у відносинах Анкари зі своїми стратегічними партнерами, насамперед - західними, а також інтенсифікації стратегічних комунікацій на цьому напрямі;

- в турецько-українських стратегічних комунікаціях, як і раніше, домінуватиме етнічно-релігійна компонента. Насамперед Анкара звертатиме увагу на дотримання прав кримських татар та інших мусульманських груп. Продовжуватиметься співпраця обох країн в економічній сфері, але при цьому не йдеться про заміну російських позицій українськими.

1 В. Аватков, А. Бадранов, «Мягкая сила» Турции во внутренней политике России [«Soft power» of Turkey in the domestic politics of Russia] URL:

2 D.Barchard, Turkey and the West. Royal Institute of International Affairs [Published for] the Royal Institute of International Affairs [by] Routledge \& Kegan Paul, 1985, 100 p. 
3 H. Şaban. Çalış. Hayaletbilimi ve Hayali Kimlikler: Yeni-Osmanlıcılık, Özal ve Balkanlar, Çizgi Kitabevi, 2006, 235 p.

4 Ш.Ганіоглу, Ататюрк: Біографія мислителя [Ataturk: Biography of a thinker], Львів, Видавництво Анетти Антоненко, Київ, Ніка-Центр, 2018, с. 95-104

5 Ю.Маврина, Концепция внешней политики Туриии Ахмета Давутоглу [Ahmet Davutoglu's Turkish Foreign Policy Concept], URL: https://cyberleninka.ru/article/n/ kontseptsiya-vneshney-politikiturtsii-ahmeta-davutoglu

6 Е. Мейгун, Свой или ТюрКСОЙ? [Own or TURKSOY?], URL: http://nazaccent.ru/content/18885svoj-ili-tyurksoj.htm

7 С. Рыбалко, «Туриия и Организация Черноморского экономического сотрудничества» [«Turkey and the Black Sea Economic Cooperation Organization»] in «Востоковедный сборник» (выпуск третий), Москва, 2002, с. 139-147.

8 Ö. Taspinar, Turkey's Middle East Policies. Between Neo-Ottomanism and Kemalism // Carnegie Middle East Center, № 10, September 2008, p. 14.

9 Ганіоглу Ш.М. Ататюрк: Біографія мислителя [Ataturk: Biography of a thinker], Львів, Видавництво Анетти Антоненко, Київ, Ніка-Центр, 2018, с. 95-104

10 Аулін О.А., Брильов Д.В., Пророченко Н.О., Ярош О.А. Іслам і політика: ідеологія, рухи, організаиіï [Islam and politics: ideology, movements, organizations], Київ, ТОВ «ДСОНІС ПЛЮС», 2019 , c. $295-299$

11 David Barchard. Turkey and the West. Royal Institute of International Affairs [Published for] the Royal Institute of International Affairs [by] Routledge \& Kegan Paul, 1985, 100 p.

12 Şaban H. Çalış. Hayaletbilimi ve Hayali Kimlikler: Yeni-Osmanlıcılık, Özal ve Balkanlar, Çizgi Kitabevi, 2006, 235 p.

13 Ö. Taspinar. Turkey's Middle East Policies. Between Neo-Ottomanism and Kemalism // Carnegie Middle East Center, № 10, September 2008, p. 14

14 Ю. Маврина, Конщепџия внешней политики Турции Ахмета Давутоглу [Ahmet Davutoglu's Turkish Foreign Policy Concept], URL: https://cyberleninka.ru/article/n/ kontseptsiya-vneshney-politikiturtsii-ahmeta-davutoglu

15 Turksoy, URL: https://web.archive.org/

16 Е. Мейгун, Свой или ТюрКСОЙ? [Own or TURKSOY?], URL: http://nazaccent.ru/content/18885svoj-ili-tyurksoj.htm;

17 С. Рыбалко, Туриия и Организащия «Востоковедный сборник» (выпуск третий), Москва, 2002, c. $139-147$

18 Державна служба статистики Украӥни. Експорт-імпорт товарів за краӥнами світу у 2016 poui [State Statistics Service of Ukraine. Export-import of goods by countries of the world in 2016] URL: http://www.ukrstat.gov.ua/

19 Терминал в Шереметьево построит турецкая Renaissance Construction [The terminal in Sheremetyevo will be built by the Turkish Renaissance Construction], URL: https://ria.ru/ economy/20160318/1392156790.html

20 Путин назвал сумму инвестиций в строительство туреикой АЭС «Аккую» [Тhe terminal in Sheremetyevo will be built by the Turkish Renaissance Construction], URL: https://ria.ru/ atomtec/20170503/149360015 8.html.

\section{References}

1. V. Avatkov, A. Badranov, «Myagkaya sila» turtsii vo vnutrenney politike Rossii (Turkey's «soft power» in Russian domestic politics] URL:

2. O. Aulin, D. Brylov, N. Prorochenko, O. Yarosh, slam i polityka: ideolohiia, rukhy, orhanizatsii [Islam and politics: ideology, movements, organizations], Kyiv, TOV «DIeONIS PLIuS», 2019, s. 295-2993.

3. Sh. Haniohlu, Atatiurk: Biohrafiia myslytelia [Ataturk: Biography of a thinker], Lviv, Vydavnytstvo Anetty Antonenko, Kyiv, Nika-Tsentr, 2018, s. 95-104.

4. David Barchard. Turkey and the West. Royal Institute of International Affairs [Published for] the Royal Institute of International Affairs [by] Routledge \& Kegan Paul, 1985, 100 p. 
5. Derzhavna sluzhba statystyky Ukrainy. Eksport-import tovariv za krainamy svitu u 2016 rotsi [State Statistics Service of Ukraine. Export-import of goods by countries of the world in 2016] URL: http:// www.ukrstat.gov.ua/

6. Ömer Taspinar. Turkey's Middle East Policies. Between Neo-Ottomanism and Kemalism // Carnegie Middle East Center, № 10, September 2008, p. 14.

7. Yu. Mavryna, Kontseptsyia vneshnei polytyky Turtsyy Akhmeta Davutohlu [Ahmet Davutoglus Turkish Foreign Policy Concept], URL: https://cyberleninka.ru/article/n/ kontseptsiya-vneshney-politikiturtsii-ahmeta-davutoglu, Turksoy, URL:

8. Yel. Meygun. Svoy ili TyurKSOY? [Own or TURKSOY?], URL: http://nazaccent.ru/content/18885svoj-ili-tyurksoj.htm

9. Putinnazval summu investitsiyv stroitelstvo turetskoy AES «Akkuyu» [The terminal in Sheremetyevo will be built by the Turkish Renaissance Construction], URL: https://ria.ru/atomtec/20170503/149360015 8.html.

10. Rybalko S.V. «Turtsiya i Organizatsiya Chernomorskogo ekonomicheskogo sotrudnichestva»[«Turkey and the Black Sea Economic Cooperation Organization»] in. «Vostokovednyy sbornik» (vypusk tretiy), Moskva, 2002, s. 139-147.

11. Şaban H. Çalış. Hayaletbilimi ve Hayali Kimlikler: Yeni-Osmanlıcllı, Özal ve Balkanlar, [Ghost Science and Imaginary Identities: Neo-Ottomanism, Ozal and the Balkans], Çizgi Kitabevi, 2006, $235 \mathrm{p}$.

12. Ö. Taspinar, Turkey's Middle East Policies. Between Neo-Ottomanism and Kemalism // Carnegie Middle East Center, № 10, September 2008, p. 14.

13. Terminal $v$ Sheremetevo postroit turetskaya Renaissance Construction [The terminal in Sheremetyevo will be built by the Turkish Renaissance Construction], URL: https://ria.ru/ economy/20160318/1392156790.html 